\title{
Okul Öncesi ve Sınıf Öğretmenlerinin Disiplinlerarası Yaklaşımın Temel Eğitimde Kullanımına Yönelik Görüșleri
}

\author{
Arefe Yurttaş ${ }^{1}$ \\ Dr. Öğr. Üyesi Eda Erdaş Kartal ${ }^{2 *}$ \\ Prof. Dr. Atila Çağlar ${ }^{3}$
}

Geliş Tarihi: 04.05.2020

Kabul Tarihi: 04.06.2020

\section{Atuf bilgisi: \\ IBAD Sosyal Bilimler Dergisi \\ Sayı: $8 \quad$ Sayfa: $226-243$ \\ Yıl: 2020 Dönem: Güz}

This article was checked by iThenticate. Similartiy Index 12\%

Bu makalede araştırma ve yayın etiğine uyulmuştur.

${ }^{1}$ Kastamonu Üniversitesi, Türkiye, arefeyurttas@gmail.com.

ORCID ID 0000-0002-8148-5745

${ }^{2}$ Kastamonu Üniversitesi, Türkiye, erdaseda@gmail.com

ORCID ID $000000021568827 \mathrm{X}$

${ }^{3}$ Kastamonu Üniversitesi, Türkiye, atilacaglar@gmail.com

ORCID ID 0000000307492688

* Sorumlu Yazar
ÖZ

Bu çalışmanın amacı, okul öncesi ve ilköğretim birinci kademede görev yapan sınıf öğretmenlerinin disiplinlerarası yaklaşım hakkındaki görüşlerinin ortaya koyulmasıdır. Araştırmada nitel araştırma desenlerinden iç içe geçmiş tekli durum deseni kullanılmıştır. Çalışmanın örneklemini 2019-2020 akademik yılında, Türkiye'nin Karadeniz Bölgesi'ndeki bir ilinde, farklı okullarda okul öncesi ve ilköğretim birinci kademede görev yapan 14 öğretmen ( 7 okul öncesi, 7 sınıf öğretmeni) oluşturmaktadır. Araştırmanın verileri öğretmenler ile yarı yapılandırılmış görüşmeler yapılarak toplanmıștır. Veri toplama aracı olarak araştırmacılar tarafindan oluşturulan yarı yapılandırılmış görüşme formu kullanılmıştır. Verilerin analizinde içerik analizi yöntemi kullanılmıștır. Araștırma sonucunda sınıf öğretmenlerinin disiplinlerarası yaklaşımı tanımlama konusunda okul öncesi öğretmenlerine göre daha iyi durumda oldukları tespit edilmiştir. Öğretmenlerin konuları çoğunlukla Türkçe, Müzik, Fen Bilimleri, Matematik ve Görsel Sanatlar dersleri ile ilişkilendirdikleri tespit edilmiştir. Okul öncesi öğretmenlerinin disiplinlerarası yaklaşımı kullanmak için ders saatlerinin genel olarak yeterli olduğunu düşündükleri tespit edilmiştir. Sınıf öğretmenlerinin çoğunlukla öğrenci seviyelerini yeterli buldukları, hem sınıf hem de okul öncesi öğretmenlerinin okul imkanlarını yetersiz buldukları tespit edilmiştir. Okul öncesi öğretmenlerinin genel olarak öğretmenler arasındaki iletişimin / etkileşimin yeterli olduğunu düşündükleri tespit edilmiştir. Öğretmenlerin disiplinlerarası yaklaşımı sınıflarında kullanmaları açısından hizmetiçi eğitimlerle desteklenmeleri önerilmiştir.

Anahtar Kelimeler: Disiplinlerarası yaklaşım, öğretmen görüşleri, temel eğitim 


\title{
Preschool and Elementary School Teachers' Views on the Use of Interdisciplinary
} Approach in Basic Education

\author{
Arefe Yurttaş ${ }^{1}$ \\ Assist. Prof. Dr. Eda Erdaş Kartal ${ }^{2 *}$ \\ Prof. Dr. Atila Çağlar ${ }^{3}$
}

First Received: 04.05.2020

Accepted: 04.06.2020

\section{Citation:}

IBAD Journal of Social Sciences

Issue: 8

Pages: $226-243$

Year: 2020

Session: Fall

This article was checked by iThenticate. Similartiy Index $12 \%$

\footnotetext{
${ }^{1}$ Kastamonu University, Turkey, arefeyurttas@gmail.com.
}

ORCID ID 0000-0002-8148-5745

2 Kastamonu University, Turkey, erdaseda@gmail.com

ORCID ID $000000021568827 \mathrm{X}$

${ }^{3}$ Kastamonu University, Turkey, atilacaglar@gmail.com

ORCID ID 0000000307492688

\section{* Corresponding Author}

\section{ABSTRACT}

The aim of this study is to reveal the views of the preschool teachers and elementary school teachers working in the first level of elementary education about the interdisciplinary approach. In this research, single-case embedded design, which is one of the qualitative research patterns, was carried out. The sample of the study is 14 teachers (7pre-school, 7 elementary teachers) working in the different preschools and first stage of elementary schools in a city on Turkey's Black Sea Region. The data of the research were collected through semi-structured interviews with teachers. A semi-structured interview form created by the researchers was used as a data collection tool. Content analysis method was used in the analysis of the data. As a result of the research, it was determined that elementary school teachers are better than preschool teachers in terms of defining interdisciplinary approach. It is determined that teachers mostly associate subjects with Turkish, Music, Science, Mathematics and Visual Arts courses. It has been determined that preschool teachers think that the lesson hours are generally sufficient to use the interdisciplinary approach. It has been determined that the elementary teachers mostly find the student levels sufficient and that both the elementary and preschool teachers find the school facilities insufficient. It has been determined that pre-school teachers generally think that communication / interaction between teachers is sufficient. It has been suggested that teachers should be supported with in-service trainings in order to use the interdisciplinary approach in their classes.

Key Words: Interdisciplinary approach, teacher views, basic education 


\section{GİRIŞ}

Bilgi, geçmişten günümüze sürekli gelişerek varllğııı devam ettiren bir olgudur. İçinde bulunduğumuz yüzyıl düşünüldüğünde teknolojik, toplumsal, kültürel gelişmelerle beraber bilginin değerinin de hızla arttığ1 görülmektedir. Dünya'daki hızlı nüfus artışının çeşitli alanlarda küresel problemler meydana getirmesiyle birlikte, bu problemlerin çözümünde, farklı disiplinlerdeki bilgi ve yöntemlerin birlikte senkronize olması başarı sağlamaktadır. Özellikle küresel olarak maruz kalınan problemlerde birbirinden ayrıymış gibi görünen birçok bilim dalı birlikte çalışmakta ve bilgiler ortaklaşa kullanılmaktadır. Dünyanın maruz kaldığı virüs (covit-19) salgınında da bu durum açık bir şekilde görülmüş ve dünya tek bir devletmiş gibi ortak hareket ederek bilgiler birlikte kullanılmaya başlanmıştır. Buradan da bilginin tüm ülkelerin ihtiyacı olan bir veri olduğu ve gelişmişliğine bakılmaksızın her ülkedeki bilginin değerli olduğu sonucuna varılmaktadır.

Eğitimin temelinde bilginin öğretimi ve kullanımı vardır. Eğitim, bireyi gerçek hayatta karşılaşılan sorunlara mantıklı çözümler üretebilecek şekilde yetiştirmeyi hedeflemektedir. Günümüz eğitiminde bireyin 21. yy becerileri arasında sayabileceğimiz bilgiyi yorumlayabilme, çıkarımda bulunma, problem çözme, analitik düşünme gibi üst düzey becerilerinin geliştirilmesi; bu sayede bireyin karşılaştığı bir probleme bütüncül olarak bakabilmesi ve problemin farklı yönlerini düşünerek disiplinlerarası bir bakış açısıyla çözüme ulaşabilmesi beklenmektedir (Uğraş, 2017). Bu beklenti bireylere, disiplinlerarası yaklaşımın öğretime dâhil edilmesi vasıtasıyla, disiplinlerarası bir bakış açısının kazandırılması ile karşılanabilir. Hızla değișen dünyaya uyum sağlayabilmek bireylerin olaylara bir bütün olarak bakabilmelerinden geçmektedir. Bu da bireyin erken yaşlardan itibaren çok yönlü düşünebilme becerisini kazanmasının önemini ortaya koymaktadır. Disiplinlerarası öğretim bireylerin çok yönlü düşünme becerilerini geliştirmelerini, ilerleyen yaşantılarında da karşılaştıkları sorunlara bütüncül yaklaşarak çözüme daha kolay ve kısa zamanda ulaşmalarını sağlayabilir. Aybek (2001) de, disiplinlerarası öğretimin farklı alanlardaki bilgiyi bir araya getirerek öğreneni üst düzey düşünmeye yönlendirdiğini, öğrenme ortamını zenginleştirdiğini, derse ilgiyi artırdığını ve öğrenenlerin yaratıcılıklarını geliştirdiğini ifade etmektedir.

Jacobs (1989) disiplinlerarası yaklaşımı "birden fazla disiplinin bilgi ve yöntemlerinin kullanılarak bir kavramın, konunun ya da problemin incelenmesi" şeklinde tanımlamaktadır. Yine disiplinlerarası yaklaşım; merkeze aldığı konunun daha iyi anlaşılması için birden fazla disiplinin bilgi, yöntem ve bakış açısını planlı bir şekilde bir araya getirme şeklinde tanımlanmaktadır (Parker, 2005; akt. Hinde, 2005). $\mathrm{Bu}$ tanımdan da anlaşılabileceği gibi konunun öğrenilmesinde farklı disiplinlerin doğasına dokunmadan, onların bilgi ve yönteminden faydalanmak esastır. Disiplinlerarası yaklaşım disiplinler arasındaki çizgiyi kaldırmamakta, onları bir araya getirerek ortak amaçlar doğrultusunda hareket etmelerini sağlamaktadır (Nolan, 1995; Young, 1998; akt. Choi ve Pak, 2006). Disiplinlerarası öğretimde belirli bir tema merkeze alınarak farklı açılardan bilgi ve beceriler bütünleştirilmektedir (Aydın ve Balım, 2005).

Toplumların sürekli gelişerek yeni bilgilere sahip olmaları, yeni çalışma alanlarını var etmiştir. Bu yeni çalışma alanlarından çevre, kaynak kullanımı, teknoloji eğitimi vb. düşünüldüğünde disipliner eğitim, özünde farklı disiplinler barındıran bu gibi konuların tam anlaşılabilmesinde kısır kalmaktadır (Yıldırım, 1996). Diğer taraftan disipliner öğretim, bu gibi konularda öğrenilen bilginin gerçek hayata aktarılmasında yetersiz kalmakta disiplinlerarası öğretim ise öğrenene bilgiyi gerçek hayatta kullanmasına olanak sağlamaktadır (Yıldırım, 1996). Ancak disiplinlerarası öğretimin gelişen ve değişen bilgi birikimlerinin aktarımında disipliner öğretime antitez olarak değerlendirilmemesi, aksine disipliner ögretimle uyum içerisinde ele alınıp uygulanması gerekmektedir (Yıldırım, 1996). Disiplinlerarası yaklaşımın mantı̆̆ 1 vücuttaki her bir organın kendine özgü görevini yerine getirirken birbirleriyle de koordineli olmasına benzetilebilir. Birinde olabilecek aksaklık diğerini etkilemektedir. Bu da vakaya bütün olarak yaklaşmayı gerektirmektedir. T1pkı bu benzetmedeki gibi bir konunun öğrenciye öğretiminde de diğer disiplinlerin perspektifinden yararlanmak gerekmektedir.

Disiplinlerarası yaklaşım konusunda yapılan çalışmalar bu konunu önemini ortaya koymaktadır. Skelly ve Zajicek (1998) disiplinlerarası bahçe faaliyet rehberi geliştirdikleri çalışmalarında, bu faaliyetlere katılan öğrencilerin çevresel tutumlarının diğerlerine göre daha olumlu bir şekilde geliştiğini ortaya koymuşlardır. Özkök (2005)'ün yaptığı çalışmada disiplinlerarası yaklaşıma dayalı olarak geliştirilen yaratıcı problem çözme öğretim programının etkileri araştırılmış, disiplinlerarası yaklaşımın bu beceri 
üzerine etkisinin olumlu olduğu sonucuna ulaşmıştır. Matthews, Adams ve Goos (2009) çalışmalarında disiplinlerarası yaklaşımın fen bilimleri ve matematik derslerinde gerçek yaşam koşullarının analiz edilmesinde yararlı olacağını öne sürmüşlerdir. Focht ve Abramson (2009) araştırmalarında, doğanın ve toplumun ortak problemlerine sürdürülebilir çözümler üretebilmek için beşeri bilimlerin, doğa bilimlerinin, uygulamalı bilimlerin ve sosyal bilimlerin disiplinlerarası sentezinin gerekli ve önemli olduğunu ortaya koymuşlardır. Karakuş, Turhan-Türkan ve Karakuş (2017) da çalışmalarında; fen ve matematik derslerinde kazanılacak bilgilerin gerçek hayattaki yerinin önemi dikkate alındığında, bu derslerin öğretiminde disiplinlerarası yaklaşıma yer verilmesi gerektiğini savunmuşlardır. Bir diğer çalışmada Doğan (2014), coğrafya dersi disiplinlerarası bir yaklaşımla işlendiğinde, öğrencilerin bilgiyi bütün haline getirebildiklerini, problemin kaynağına inebildiklerini, ders içinde aktif olduklarını ve iş birliği ile çalışmalarında koordineyi iyi bir şekilde sağlayabildiklerini vurgulamıştır. Araştırmacı bu durumun öğrencilerin çeşitli bakış açıları geliştirmelerini sağladığını ve öğrencilerin öğrendiklerini gerçek hayata uygulama becerilerini geliştirdiğini ortaya koymuştur. Gürkan (2015) doktora tez çalışmasında dördüncü sınıf öğrencilerinin, öğretmenlerinin sosyal bilgiler dersini disiplinlerarası yaklaşıma dayalı bir şekilde işlemesini olumlu bir şekilde değerlendirdiklerini belirtmiştir. Yine Turan (2019) 2018 sosyal bilgiler öğretim programını disiplinlerarası yaklaşım açısından incelemiş, yeni düzenlemelerle sosyal bilimler dersi konularının farklı dispilinlerle ilişkilendirilerek kazanımların verildiğini belirtmiştir. Başka bir çalışmada ise Türkçe dersinin beceri dersi (okuma, dinleme, konuşma, yazma) olmasından kaynaklı olarak disiplinlerarası öğretim için oldukça elverişli olduğu ifade edilmiştir (Kanatlı ve Çekici, 2013). Disiplinlerarası fen öğretiminin sürdürülebilir kalkınma konusundaki etkilerinin incelendiği bir çalışmada ise öğrencilere disiplinlerarası yaklaşımla geliştirilen etkinlikler uygulandığında biyolojik çeşitlilik, toprak kirliliği, açlık, yenilenebilir-yenilenemez enerji kaynakları, geri dönüşüm konularında olumlu yönde ilerleme kat ettikleri belirtilmiştir (Aytar ve Özsevgeç, 2019).

Öğretimin ilk basamağını okul öncesi dönemi ve bunu takip eden ilköğretimin birinci kademesi oluşturmaktadır. Temel eğitimin kalitesi sonraki eğitim kademelerinin kalitesini de etkilemektedir. $\mathrm{Bu}$ nedenle öğretimin ilk basamağı sonraki basamaklar için temel niteliğindedir ve önemlidir. Okul öncesi eğitimde ve ilkokulda verilen disiplinlerarası öğretim, öğrencinin bir konuyu farklı disiplinlerle birlikte ele alarak bütünsel olarak değerlendirmesini sağlamaktadır. Zaten küçük yaştaki öğrenciler bir konuyu, bir olayı bütün olarak algılama eğilimindedir. İlkokula giden bir öğrenciye "Atatürkçülük denildiğinde aklına neler gelir?" diye sorulduğunda, büyük olasılıkla öğrencinin aklına "insan sevgisi, barış, zafer, vatan, iyi plan yapma (matematiksel zekâ), başöğretmen, çocuk sevgisi, özgürlük" ile Atatürk Orman Çiftliği'nden yola çıkarak "doğa sevgisi” gibi değişik disiplinleri kapsayan kavramlar gelecektir. Bu nedenle özellikle okul öncesi dönem ve ilköğretim birinci kademede olabildiğince disiplinlerarası yaklaşımın tercih edilmesi uygundur. Gülay-Ogelman ve Durkan, 2014 yılında yaptıkları çalışmada bir toprak eğitimi projesi gerçekleştirmiş ve bu projeye katılan 5-6 yaş çocukların toprak ve toprakla ilgili kavramlar hakkındaki bilgilerindeki değişimi araştırmışlardır. Araştırma sonucunda disiplinlerarası yaklaşımın esas alındığı deney grubundaki uygulamaların, bu gruptaki çocukların bilgilerini kontrol grubundaki çocuklara göre daha fazla arttırdığını ortaya koymuşlardır. Demir (2009) ise, ilköğretim ikinci sınıflarda uygulanan disiplinlerarası bütüncül öğretim yaklaşımının etkisini araştırdığı çalışmasında, deney ve kontrol grubu arasında deney grubu lehine öğrenci başarısı anlamında büyük ölçüde fark olduğunu tespit etmiştir. Deney grubundaki öğrenciler disiplinlerarası etkinlikleri çok beğendiklerini, bu etkinliklerin oldukça ilgilerini çektiğini, konuları kolay anladıklarını ve öğrendiklerini daha iyi hatırlayabildiklerini, derse katılmaya daha istekli hale geldiklerini ve öğrendikleri bilgilerin hayatta kullanılabilirliğinin arttı̆̆ını düşündüklerini, özetle bu yaklaşımla derslerin onlar için daha kolaylaştığını düşündüklerini ifade etmişlerdir. $\mathrm{Bu}$ alanda yapılan çalışmalardan disiplinlerarası yaklaşıma dayalı öğretimin yararlarının oldukça fazla olduğu göze çarpmaktadır.

Öğretmenler öğretimde kritik bir rol üstlenmektedir. Öğretmenlerin disiplinlerarası yaklaşım konusunda yeterli bilgiye sahip olmaları, eğitim öğretimin kalitesi açısından önemli olduğu düşünülmektedir. Okul öncesi ve ilköğretim birinci kademe öğretim programları öğretmenin bir kazanımı öğrenciye vermesi için esneklik sağlamaktadır. Öğretim programlarındaki bu esnekliği en verimli şekilde planlayıp uygulamak ise öğretmenlerin görevidir. Alan yazın incelendiğinde okul öncesi dönem ve ilköğretim birinci kademede disiplinlerarası yaklaşımın öğretmen görüşleri bağlamında araştırıldığı ulusal düzeyde bir çalışmaya rastlanmamıştır. Alan yazındaki bu boşluğu doldurmaya katkı sağlamak adına bu çalışmanın 
amac1, okul öncesi ve ilköğretim birinci kademede görev yapan sınıf öğretmenlerinin disiplinleraras1 yaklaşım hakkındaki görüşlerinin ortaya konulması olarak belirlenmiştir. $\mathrm{Bu}$ amaç doğrultusunda aşağıdaki alt problemlere cevap aranmıştır:

1. Öğretmenler disiplinlerarası yaklaşımı nasıl tanımlamaktadır?

2. Öğretmenlerin disiplinlerarası yaklaşımı kullanma /kullanmama nedenleri nelerdir?

3. Öğretmenler hangi konuları disiplinlerarası yaklaşım ile öğretime uygun bulmaktadır?

4. Öğretmenler disiplinlerarası yaklaşımı kullanırken çoğunlukla hangi derslerle ilişkilendirmektedir?

5. Öğretmenlerin disiplinlerarası yaklaşımı kullanmak için ders saatlerinin, öğrenci seviyesinin, okul imkânlarının ve zümreleri arasındaki iletişimin/işbirliğinin yeterliliğine yönelik görüşleri nelerdir?

6. Öğretmenlerin disiplinlerarası yaklaşımın kullanımına yönelik önerileri nelerdir?

\section{YÖNTEM}

\section{Araştırma Deseni}

$\mathrm{Bu}$ araştırma, disiplinlerarası yaklaşımın temel eğitimde kullanımına yönelik okul öncesi ve ilköğretim birinci kademede çalışan ögretmen görüşlerinin nitel araştırma yöntemleri ile belirlendiği bir durum çalışması (case study)'dır. Nitel çalışmalar sosyal olguların ve olayların bulunduğu doğal ortamda gerçekçi ve bütüncül olarak ele alındığı/incelendiği çalışmalardır. Durum çalışması ise araştırmacıların belirli bir olgu ya da olayı derinlemesine incelemesine olanak veren nitel bir araştırma çeşitidir (Yıldırım ve Şimşek 2013). Araştırma nitel araştırma desenlerinden iç içe geçmiş tek durum deseni (single-case embedded design) ile tasarlanmıştır. İç içe geçmiş tek durum deseni, belirli bir durum için birden fazla alt birimin veya tabakanın bulunduğu bir durum desenidir (Yin, 1984; akt: Subaş1 ve Okumuş, 2017). Bu araştırmada sınıf öğretmenleri ve okul öncesi öğretmenleri iki ayrı tabaka olarak kabul edilmektedir. Bu iki tabakada tek bir durum (disiplinler arası öğretim hakkındaki görüşler) araştırılmıştır.

\section{Örneklem}

Çalışmanın örneklemini 2019-2020 akademik yılında, Türkiye'nin Karadeniz Bölgesi’ndeki bir ilinde, farklı okullarda okul öncesi ve ilköğretim birinci kademede görev yapan 14 öğretmen ( 7 okul öncesi, 7 sınıf) oluşturmaktadır (Tablo 1). Örneklemin belirlenmesinde, devlet okullarındaki ana sınıfı ve ilköğretim birinci kademede görev yapma ve çalışmaya katılmak için gönüllü olma ölçütleri dikkate alınmıştır.

Tablo 1. Araştırmaya Katılan Öğretmenlerin Özellikleri

\begin{tabular}{llll}
\hline Değişken & Kategori & f & Örneklem \\
\hline Cinsiyet & Kadın & 13 & O1, O2, O3, O4, O5, O6, O7, S1, \\
& Erkek & & S2,S3, S5, S6, S7 \\
& $30-40$ & 1 & S4 \\
\hline Yaş & $41-50$ & 7 & O1, O2, O3, O4, O7, S2, S4 \\
& 50 üstü & 4 & O5, O6, S6, S7 \\
& Ön Lisans & 3 & S1, S3, S5 \\
\hline Eğitim durumu & Lisans & 1 & S7 \\
& Lisans Üstü & 12 & O1, O2, O3, O4, O5, O6, O7, S1, \\
& Okul Öncesi Öğretmenliği & 7 & S3, S4, S5, S6 \\
\hline Branş & Sinıf Öğretmenliği & 6 & O1, O2, O3, O4, O5, O6, O7 \\
& Diğer & 1 & S6 S2, S3, S4, S5, S7 \\
\hline Çalıştığ1 yer & Merkez & 13 & O1, O2, O3, O4, O5, O6, O7, S1 \\
& & & S2, S3, S5, S6, S7 \\
& Köy & 1 & S4 \\
\hline Sinıfindaki öğrenci sayıs1 & $11-15$ & 4 & O3, O4, S4,O6 \\
& $16-20$ & 3 & O1, O2, O5
\end{tabular}




\begin{tabular}{llll} 
& $21-25$ & 4 & O7, S2, S3, S7 \\
& $26-30$ & 2 & $\mathrm{~S} 1, \mathrm{~S} 6$ \\
& 30 üstü & 1 & $\mathrm{~S} 5$ \\
\hline Hizmet y1lı & $5-10$ & 3 & $\mathrm{O} 2,07, \mathrm{~S} 4$ \\
& $11-15$ & 3 & O1, O3, O4 \\
& $16-20$ & 2 & O6, S2 \\
& $21-25$ & 2 & O5, S6 \\
& $26-30$ & 3 & $\mathrm{~S} 3,29, \mathrm{~S} 7$ \\
\hline Günlük eğitim amaçlı & 30 üstü & 1 & $\mathrm{~S} 1$ \\
teknoloji kullanma siklığ1 & Yarım saat-1 saat & 2 & O1, S1 \\
& 1 saat-1,5 saat & 3 & O2, S3, S6 \\
& 1,5 saat- 2 saat & 5 & O3, O4, O5, S2, S7 \\
& 2 saat- 2,5 saat & 0 & - \\
& 2,5 saat-3 saat & 1 & O6 \\
& 3 saat üstü & 3 & O7, S4, S5 \\
\hline
\end{tabular}

\section{$\mathrm{N}: 14$}

\section{Veri Toplama Yöntemi}

Araştırmanın verileri öğretmenler ile yarı yapılandırılmış görüşmeler yapılarak toplanmıştır. Veri toplama aracı olarak araştırmacılar tarafından oluşturulan yarı yapılandırılmış görüşme formu kullanılmıştır. Sorular hazırlandıktan sonra görüşme formu bir dil ve bir alan uzmanına gösterilmiştir. Sonraki aşamada asıl örneklemin dışındaki 4 öğretmen ( 2 okul öncesi, 2 sınıf) ile görüşme yapılmış ve anlaşılmayan sorular revize edilerek görüşme formuna son şekli verilmiştir. Görüşme formu 17 açık uçlu sorudan oluşmaktadır. Bu sorulardan 8 tanesi öğretmenlerin demografik özelliklerini belirlemeye yönelik, 9 tanesi ise öğretmenlerin disiplinlerarası yaklaşımla ilgili görüşlerini belirlemeye yöneliktir. Dokuz sorudan ilki birinci araştırma problemi ile ilgili; ikincisi ikinci araştırma problemi ile ilgili; üçüncüsü üçüncü araştırma problemi ile ilgili; dördüncüsü dördüncü araştırma problemi ile ilgili; beşinci, altıncı, yedinci ve sekizincisi beşinci araştırma problemi ile ilgili; dokuzuncusu ise altıncı araştırma problemi ile ilgilidir. Görüşmeler öğretmenlerin kendilerini rahat hissedecekleri, tercih ettikleri bir mekanda yapılmıştır. Her bir görüşme ortalama 40-45 dakika sürmüştür.

\section{Veri Analiz Yöntemi}

Verilerin analizinde içerik analizi yöntemi kullanılmıştır. İçerik analizinde amaç verilerin kavramsallaştırılması ve olguyu tanımlayabilecek temaların ortaya çıkarılmasıdır. Bu amaçla içerik analizinde birbirine benzeyen veriler belirli kavramlar ve temalar altında biraraya getirilir. Daha sonra bu veriler bulguların kolay anlaşılabilmesini sağlayacak şekilde düzenlenerek yeniden yorumlanır (Yıldırım ve Şimşek, 2013). Bu doğrultuda ilk etapta görüşmeler transkript edilmiştir. Transkript edilen verilerin yarısı genel fikir edinmek amacıyla iki araştırmacı tarafından gözden geçirilmiş ve hazırlanan kod listesinden faydalanılarak iki araştırmacı tarafından ayrı ayrı kodlanmıştır. Araştırmacıların yapmış olduğu kodlamalar arasındaki tutarlılık Miles ve Huberman (1994)'ın güvenirlik formülü kullanılarak hesaplanmıştır. Araştırmacıların kodlamaları arasındaki tutarlılık \%94 olarak hesaplanmıştır. Tutarlılık sağlanamayan kodlamalar yeniden gözden geçirilerek ortak görüş benimsenmiştir. Yapılan kodlamalar alan uzmanı olan üçüncü araştırmacı tarafından tekrar gözden geçirilmiştir. Bulgular belirli kategori ve temalar altında bir araya getirilerek betimsel tablolar halinde sunulmuştur.

Bulgular sunulurken içerik analizinin doğasına uygun olarak öğretmen görüşlerinden doğrudan alıntılara yer verilmiştir.

\section{BULGULAR}

Bu bölümde bulgular araştırma problemlerine göre sırayla sunulmuştur. Altı araştırma problemi ile ilgili bulgular altı alt başlık halinde raporlanmıştır.

\section{Öğretmenlerin Disiplinlerarası Yaklaşımın Tanımına Yönelik Görüşleri}

Okul öncesi ve sınıf öğretmenlerinin disiplinlerarası yaklaşım ile ilgili tanımlamaları Tablo 2'de sunulmuştur. 
Tablo 2. Öğretmenlerin Disiplinlerarası Yaklaşım İlişkin Tanımlamaları

\begin{tabular}{lll}
\hline Branşlar & Temalar & Öğretmenler \\
& Bir kazanımın farklı derslerde de kullanılması & O1 \\
\multirow{3}{*}{ Okul } & Bütünleştirilmiş etkinlik & O2 \\
& Davranışlar ve kazanımlar üzerine çalışma & O5 \\
& Eğitim modelleri baz alınarak eğitim-öğretime şekil verme & O6 \\
& Kismen biliyorum ama tanımlayamam & O3, O4, O7 \\
\hline \multirow{2}{*}{ Sınıf } & Bir konunun birden fazla farklı dersin kazanımlarıyla ilişkilendirilmesi & $\mathrm{S} 1, \mathrm{~S} 2, \mathrm{~S} 3, \mathrm{~S} 4, \mathrm{~S} 5$ \\
& Hayat ile derslerin ilişkilendirilmesi & $\mathrm{S} 3$ \\
& Bir konunun görsel, zihinsel, işitsel, bedensel bütünlükle verilmesi & $\mathrm{S} 6$ \\
& Bilmiyorum & $\mathrm{S} 7$ \\
\hline
\end{tabular}

Tablo 2 incelendiğinde okul öncesi öğretmenlerinin üçü (f:3) kısmen bildiklerini ancak tanımlayamayacaklarını söylemişlerdir. Bu ifadeleri veren öğretmenlerden O7'nin açıklaması “ísmini duydum ama açıklayacak kadar bilgim yok" şeklinde olup, diğer iki öğretmenin açıklaması ise kısmen bildikleri yönündedir. Bu konuda öğretmenlerden O6 "biliyorum, eğitim modellerini baz alarak eğitim-ögretime şekil verme”, O5 "önceden ismini bilmiyordum, davranış ve kazanımlar üzerinde uyguluyorum", $\mathrm{O} 2$ "bütünleştirilmiş etkinlik olarak biliyorum ve etkinliklerimde kullanıyorum", $\mathrm{O} 1$ "bir kazanımın farklı derslerde de kullanılması" şeklinde açıklamalarda bulunmuşlardır.

Tablo 2'ye göre sınıf öğretmenlerinin dördü (f:5) disiplinlerarası yaklaşımı "bir konunun birden fazla farklı dersin kazanımlarıyla ilişkilendirilmesi" şeklinde ifade etmişlerdir. Bu şekilde ifade eden öğretmenlerden S1, disiplinlerarası yaklaşımı "bir konuya diğer ve birden fazla farkl derste yer verilmesi olarak biliyorum" şeklinde ifade etmiştir. S2 ise disiplinleraras1 yaklaşımı "bir konunun diğer derslerle bağdaşım kurularak anlatılması ve konunun böylelikle pekiş̧irilmesi; mesela matematik dersinde işlediğimiz sayılar konusunu müzik dersinde 'sayılar' şarkısıyla pekiştirme" olarak tanımlamışır. S4 disiplinlerarası yaklaşımı "bir dersteki kazanımın başka bir dersle ilişkilendirilerek işlenmesidir. Bu sayede ilgili kazanım hem farklı alanlarda ilişkilendirilir ve ilgili alan pekişstirilmiş olur" şeklinde; S5 ise "Türkçe dersi ile ilgili bir konuyu, Görsel Sanatlar dersi ile bağlamak" şeklinde tanımlamıştır. Araştırmada öğretmenlerden S7 ise disiplinlerarası yaklaşımı bilmediğini söylemiştir. Yine konu ile ilgili araştırmaya katılan sınıf öğretmenlerinden bazılarının görüşü şu şekildedir:

“Biliyorum. Dersler arası iliş̧kidir. Hayat ile derslerin ilişkisidir de.” S3

"Biliyorum, bir konuyla ilgili olarak, bir kazanım verilirken görsel, zihinsel, işitsel bütünlükle kazanımın verilmesidir." S6

\section{Öğretmenlerin Disiplinlerarası Yaklaşımı Kullanma /Kullanmama Nedenleri}

Okul öncesi ve sınıf öğretmenlerinin disiplinlerarası yaklaşımı kullanma /kullanmama nedenleri Tablo 3 'te özetlenmiştir.

Tablo 3. Öğretmenlerin Disiplinlerarası Yaklaşımı Kullanma/Kullanmama Nedenleri

\begin{tabular}{|c|c|c|c|}
\hline Branşlar & Temalar & Kategoriler & Öğretmenler \\
\hline & & Öğrenmeyi artırma & O1, O6 \\
\hline & & Pekiştirmeyi sağlama & $\mathrm{O} 1, \mathrm{O} 2$ \\
\hline & & Farklı açılardan öğrenme becerisini geliştirme & O1, O6, O7 \\
\hline & & Farklı zekâ alanlarına hitap etme & O1, O6, O7 \\
\hline & & İletişimi kolaylaştırma & O1 \\
\hline & & Öğretimi kolaylaştırma & $\mathrm{O} 1, \mathrm{O} 3, \mathrm{O} 7$ \\
\hline & & Kopukluğu önleme & $\mathrm{O} 1, \mathrm{O} 4$ \\
\hline \multirow[t]{3}{*}{ Okul öncesi } & Kullaniyorum & Etkinliklerde süre ve çeşitlilikte esneklik sağlama & $\mathrm{O} 1, \mathrm{O} 6$ \\
\hline & & Öğrencinin öz güvenini geliştirme & $\mathrm{O} 5$ \\
\hline & & Öğrencinin öz bakım becerisini geliştirme & O5 \\
\hline
\end{tabular}




\begin{tabular}{|c|c|c|c|}
\hline & & $\begin{array}{l}\text { Öğrencinin araştırma becerisini geliştirme } \\
\text { Öğrencinin sabırlı olma becerisini geliştirme }\end{array}$ & $\begin{array}{l}\mathrm{O} 5 \\
\mathrm{O} 5\end{array}$ \\
\hline \multirow{6}{*}{ Sinif } & \multirow{5}{*}{ Kullanıyorum } & Pekiştirmeyi sağlama & $\mathrm{S} 1, \mathrm{~S} 2$ \\
\hline & & Kalıcılığı sağlama & S3 \\
\hline & & Farklı zekâ alanlarına hitap etme & S4 \\
\hline & & Ölçme ve değerlendirmede fayda sağlama & S5 \\
\hline & & Konu anlatımını zenginleştirme & S6 \\
\hline & Kullanmiyorum & Bilgi eksikliği & S7 \\
\hline
\end{tabular}

Tablo 3 incelendiğinde okul öncesi öğretmenleri tümü disiplinlerarası yaklaşımı kullandıklarını ifade etmişlerdir. Araştırmadaki O1, O6 ve O7 öğretmenler disiplinlerarası yaklaşımı "öğrencilerin farklı açılardan öğrenme becerileri geliştirdiğini, aynı zamanda farklı zeka alanlarına hitap ettiğini" düşündükleri için kullandıklarını belirtmişlerdir. Araştırmada $\mathrm{O} 1, \mathrm{O} 3$ ve $\mathrm{O} 7$ ise disiplinlerarası yaklaşımı kullanım nedenini "öğretimi kolaylaştırması" olarak açıklamışlardır. Yine öğretmenlerden O1 ve O4 disiplinlerarası yaklaşımı "kopukluğu önlemesi" nedeniyle kullandıklarını ifade etmişlerdir. Okul öncesi öğretmenlerden O1 ve O6 disiplinlerarası yaklaşımı kullanma nedenleri olarak "etkinliklerde süre ve çeşitlilikte esneklik sağlamasını" göstermişlerdir.

Araştırmada öğretmenlerin disiplinlerarası yaklaşımı kullanma nedenleri ile ilgili olarak vermiş oldukları cevaplar bazıları şu şekildedir:

“Kullanıyorum. Anlaşılması zor olan konuların verilmesinde kolaylık sağllyor.” O3

"Kullanıyorum. Etkinlikler arası geçişlerde kolaylık sağllyor. Etkinlikleri, öğrenilmesi zor konuların verilmesinde kolaylık sağllyor." $\mathrm{O} 4$

"Evet kullaniyorum. Öğrenmeyi artırma (pekiştirme) farklı açılardan öğrenme becerisi, farklı zeka alanlarına hitap etme, iletişimi ve ögretimi kolaylaştırıyor, kopukluk olmuyor. ” $\mathrm{O} 1$

"Konuyu farkl alanlarda sunarak gün içinde verilmesi istenen kazanımı pekiştiriyor. O sebeple birbiri ile bağlantılı olmasina dikkat ediyorum." $\mathrm{O} 2$

"Öğrencinin kendisine güvenmesi, öz bakım becerilerini gelişmesi, araştırma becerilerinin artması, sira beklemesi, sabirl olmast." O5

"Kullanıyorum. Sinıfta etkinlik çeşitliliği amaçlı, farklı gelim gösteren çocuklara farklı yöntemlerle öğretebilme amaçlı kullanıyorum." $\mathrm{O} 6$

Tablo 3 incelendiğinde sınıf öğretmenlerinin disiplinlerarası yaklaşımı kullanma nedenleri "pekiştirmede etkili olması" S1 ve S2; "kalıcıllğı sağlaması" S3; "farkl zeka yapılarına hitap etmesi" S4; "ölçme ve değerlendirmede fayda sağlaması" S5; "konu anlatımını zenginleştirmesi" S6 şeklindedir. Araştırmaya katılan sınıf öğretmeni S7 ise disiplinlerarası yaklaşımı bilmediğini, bu nedenle de kullanmadığını belirtmiştir. Araştırmada öğretmenlerden alınan yanıtlardan bazıları şöyledir:

“Kullanmaya çalışıyorum. Konunun pekiştirilmesine yardımcı oluyor.” S1

"Kullanıyorum. Hayat Bilgisi dersinde mevsimler konusunu ögretirken Müzik dersinde bununla ilgili bir şarkı söyledik. Böylece konu pekiştirilmiş ve daha kalıcı olmuş oldu.” S2

"Kullanıyorum. Sağlıklı beslenme konusu işlenirken görsel, müzik, drama etkinlikleri ile konuyu veriyorum." S6

"Kullanıyorum. Örneğin Türkçe dersindeki konu ile görsel sanatlarda çizim yapabiliyorsa konuyu anladiğını da anlayabiliyorum." S5

"Evet kullanıyorum. Farklı alanlarda kullanılan ve yapılan bağdaştırmaların farklı zeka yapısına sahip çocuklar açısından etkisi olacağına inanıyorum. Yani Türkçe dersinde anlayamayan bir ögrenci, Hayat Bilgisi dersinde ilgili kazanımı kavrayabiliyor." S4

“Kazanımların daha kalıcı olması için kullanıyorum.” S3 


\section{Öğretmenlerin Disiplinlerarası Yaklaşım İle Öğretime Uygun Buldukları Konular}

Okul öncesi ve sınıf öğretmenlerinin disiplinlerarası yaklaşım ile öğretime uygun buldukları konular Tablo 4'te özetlenmiştir.

Tablo 4. Öğretmenlerin Disiplinlerarası Yaklaşım İle Öğretime Uygun Buldukları Konular

\begin{tabular}{lll}
\hline Branş & Temalar & Öğretmenler \\
\hline \multirow{3}{*}{ Okul öncesi } & Sağlı ile ilgili konular & O1, O2, O3, O4, O7 \\
& Çevre & O1, O3, O4, O7, O2, O6 \\
& Meslekler & O2, O7 \\
& Değerler eğitimi & O5 \\
& Ses bilgisi & O6 \\
& Şekiller ve sayılar & O7 \\
& Zit kavramlar & O7 \\
& Renkler & O7 \\
& Fen ve Matematik konuları & O3, O4, O6 \\
\hline \multirow{3}{*}{ Sinıf } & Matematik konuları & $\mathrm{S} 1, \mathrm{~S} 2, \mathrm{~S} 4, \mathrm{~S} 5, \mathrm{~S} 6$ \\
& Davranış kazandirma ve kurallar & $\mathrm{S} 2$ \\
& Tüm hayat bilgisi konuları & $\mathrm{S} 3, \mathrm{~S} 4$ \\
& Atatürk ile ilgili konular & $\mathrm{S} 4$ \\
& Sağlı & $\mathrm{S} 4, \mathrm{~S} 5, \mathrm{~S} 6$ \\
& Beslenme & $\mathrm{S} 4, \mathrm{~S} 6$ \\
& Teknoloji & $\mathrm{S} 4$ \\
Dilbilgisi & $\mathrm{S} 6$ \\
\hline
\end{tabular}

Tablo 4'te okul öncesi öğretmenlerinin ders işlerken disiplinlerarası yaklaşımı tercih ettikleri konuların dağılımı verilmiştir. En fazla tercih ettikleri konular sırasıyla; çevre (f: 6), sağlıkla ilgili konular (f: 5), genel olarak fen ve matematik konuları (f: 3), meslekler (f: 2), değerler eğitimi (f: 1), ses bilgisi (f: 1), şekiller ve sayılar (f: 1), zıt kavramlar (f: 1), renkler (f: 1)'dir.

Araştırmaya katılan okul öncesi öğretmenlerinden bazılarının görüşleri şu şekildedir:

"Sanat etkinliği, matematik ve müzik dersi ile să̆lık konularını anlatıyorum." $\mathrm{O} 2$

"Sanat etkinliği, fen ve doğa ve müzik dersi ile mevsimler konusunu anlattyorum.” $\mathrm{O} 2$

"Sanat etkinliği, müzik ve drama ile meslekler konusunu anlatiyorum. ” 2

"Matematik ve fen-doğa konular bu anlamda daha uygundur." $\mathrm{O} 4$

"Fen ve matematik konularına ait kazanımların disiplinlerarası yaklaşım ile öğretiminin daha uygun olduğunu düşünüyorum.” $\mathrm{O} 3$

"Sosyal gelişim alanına ait olan çevreye ve diğer canlılara saygı gösterir kazanımını verirken kullanmayl uygun buluyorum.” O6

"Dil gelişimi alanına ait ses bilgisi farkındalığı gösterir kazanımı için uygundur. ” O6

Tablo 4 incelendiğinde sınıf öğretmenlerinin disiplinlerarası yaklaşıma uygun buldukları konular sırasıyla matematik konuları (f: 5), sağlık (f: 3), beslenme (f: 2), tüm hayat bilgisi konularında (f: 2), davranış kazandırma ve kurallar (f: 1), Atatürk ile ilgili konular (f: 1), teknoloji (f: 1), noktalama işaretleri konusu (f: 1) şeklindedir. Araştırmadaki öğretmenlerden S7 disiplinlerarası yaklaşımı bilmediği ve kullanmadığı için bu soruya yanıt vermemiştir. Öğretmenlerin konu ile ilgili soruya vermiş oldukları yanıtların bazıları şöyledir:

"Hayat bilgisi dersinde 'Büyüklerimizin çocukluğunda oynadiğı oyunlar' konusunu Beden Eğitimi ve Oyun dersinde oynayıp ögreniyoruz.” S3

"Atatürk ile ilgili kazanımlar, sayılar, günlük hayata ilişkin Hayat Bilgisi Dersi kazanımları, sağllklı beslenme, teknoloji, geçmişten günümüze yaşanılan değişimler vb. Bütün dersler arasinda 
disiplinlerarası yaklaşım uygulanabilirken; Türkçe, Matematik ve Hayat Bilgisi derslerinde bu kullanımın daha fazla olduğunu düşünüyorum." S4

"Her ders birbiri ile iliş̧ilendirilebilir. Noktalama işaretleri bir rap şarklsılyla verilebilirken, matematikte bir problem canlandirma ile verilebilir." S6

"Problem çözümü sırasında, Türkçe dersi ile Matematik dersi arasinda disiplinler arası geçiş sağlayabiliriz. Görsel Sanatlar dersi ile Türkçe dersi arasında yine disiplinlerarası geçiş sağlanabilir." S2

"Matematik dersindeki doğal sayıları büyükten küçüğe veya küçükten büyüğe siralama kazanımını, sosyal bilgiler dersindeki kronolojik siralama konusu ile tekrar edebiliyorum." S1

\section{Öğretmenlerin Disiplinlerarası Yaklaşımı Kullanırken Konuları İlişkilendirdikleri Dersler}

Okul öncesi ve sınıf öğretmenlerinin disiplinlerarası yaklaşımı kullanırken konuları ilişkilendirdikleri dersler Tablo 5'te sunulmuştur.

Tablo 5. Öğretmenlerin Disiplinlerarası Yaklaşımı Kullanırken Konuları İlişkilendirdikleri Dersler

\begin{tabular}{lll}
\hline Branşlar & Temalar & Öğretmenler \\
\hline \multirow{3}{*}{ Okul öncesi } & Sanat Etkinlikleri & O1, O7 \\
& Fen Bilimleri & O1, O2, O7 \\
& Matematik & O1, O2 \\
& Türkçe & O1, O2, O5, O7 \\
& Bilişim ve Teknoloji & O1 \\
& Müzik & O2, O3, O4, O5 \\
\hline Sinıf & Matematik & S1, S2, S4 \\
& Sosyal Bilgiler & $\mathrm{S} 1$ \\
& Fen Bilimleri & $\mathrm{S} 1$ \\
& Türkçe & $\mathrm{S} 2, \mathrm{~S} 4, \mathrm{~S} 5$ \\
& Görsel Sanatlar & $\mathrm{S} 2, \mathrm{~S} 3, \mathrm{~S} 5$ \\
& Hayat Bilgisi & $\mathrm{S} 3, \mathrm{~S} 4$ \\
& Beden Eğitimi & $\mathrm{S} 3$ \\
& Müzik & $\mathrm{S} 3$ \\
Her ders & $\mathrm{S} 6$ \\
\hline
\end{tabular}

Tablo 5 incelendiğinde okul öncesi öğretmenlerinin disiplinlerarası yaklaşımı kullanırken konuları en fazla ilişkilendirdikleri dersler sırasıyla Türkçe (f: 4), müzik (f: 4), fen bilimleri (f: 3), sanat etkinlikleri (f: 2), matematik (f: 2), bilişim teknolojisi (f: 1) şeklindedir. Öğretmenlerden O1'in yanıtı aşağıdaki gibidir:

"Sağllk ile ilgili konuları sanat etkinliği, matematik, müzik; mevsimler konusunu sanat etkinliği, fen ve doğa etkinliği, müzik; meslekler konusunu sanat etkinliği, müzik, ve drama etkinliklerini kullanarak ögretiyorum.” $\mathrm{O} 2$

Tablo 5'te gösterildiği gibi sınıf öğretmenlerinin disiplinlerarası yaklaşımı kullanırken konuları en fazla ilişkilendirdikleri dersler sırayla Matematik (f: 3), Türkçe (f: 3), Görsel Sanatlar (f: 3), Hayat Bilgisi (f: 2), Sosyal Bilimler (f: 1), Fen Bilimleri (f: 1), Beden Eğitimi (f: 1), Müzik (f: 1)'tir. Araştırmaya katılan öğretmenlerden S6, konuların her derste ilişkilendirilebileceğini (f: 1) ifade etmiştir. Öğretmenlerin cevaplarından bazıları şöyledir:

"Matematik dersindeki zaman ölçüleri konusundaki gün, mevsim, ay, yıl kazanımları Fen Bilimleri dersinde Dünya'nın hareketleri konusu eşleştirilebilmektedir." S1

“Görsel sanatlar, sözlü anlatım ve çoklu zeka uygulamalarını kullanıyoruz.” S5

“En çok Türkçe, matematik, hayat bilgisi dersleri ile ilişkilendirdiğimi düşünüyorum." S4 
Öğretmenlerin Disiplinlerarası Yaklaşımı Kullanmak İçin Ders Saatlerinin, Öğrenci Seviyelerinin, Okul İmkânlarının ve Zümreleri Arasındaki İletişimin/Isşbirliğinin Yeterliliğine Yönelik Görüşleri

Okul öncesi ve sınıf öğretmenlerinin disiplinlerarası yaklaşımı kullanmak için ders saatlerinin yeterliliğine yönelik görüşleri Tablo 6'da sunulmuştur:

Tablo 6. Öğretmenlerin Ders Saatlerinin Yeterliliğine Yönelik Görüşleri

\begin{tabular}{lll}
\hline Branşlar & Temalar & Öğretmenler \\
\hline Okul öncesi & Yeterli & O1, O2, O3, O4, O6, O7 \\
& Yetersiz & O5 \\
\hline \multirow{2}{*}{ Sinıf } & Yeterli & S1, S3 \\
& Yetersiz & S2, S4, S5 \\
& Bazen Yeterli/Bazen Yetersiz & S6, S7 \\
\hline
\end{tabular}

Tablo 6'da okul öncesi öğretmenlerinin disiplinlerarası yaklaşımı uygulamak için programda ayrılan ders saatlerinin yeterli olduğunu (f:6) düşündükleri görülmektedir. Araştırmaya katılan okul öncesi ögretmeni O5'in bu konu ile ilgili ifadesi şu şekildedir:

"Yeterli değil. Bazen aile katılımının gerekli olduğu durumlar oluyor."

Tablo 6'da belirtildiği gibi sınıf öğretmenleri programda ayrılan ders saatlerinin disiplinlerarası yaklaşımı uygulamak için yeterli (f: 2), yetersiz (f: 3) ve bazen yeterli bazen yetersiz (f: 2) bulmaktadırlar. Araştırmaya katılan öğretmenlerin ifadeleri şu şekildedir:

"Bazı konular için ayrılan ders saatlerini fazla, bazılarını ise yetersiz buluyorum. Bazı kazanımların daha fazla süreye yayılmasının faydalı olacağına inanıyorum. Ayrıca birleştirilmiş sınıflar için zaman önemli bir sorun arz ediyor." S4

“...Konular farklılaştıkça yeterli olmadığı durumlarda oluyor. Örneğin sosyal bilgiler dersinde milli mücadele konusu için ayrılan zaman yeterli olamadı.” S6

“4.sınıf hariç yeterli olduğunu düşünüyorum.” S7

“Maalesef yeterli olmadiğını düşünüyorum." S2

"Derslere branş ögretmenler girmediği için disiplinlerarası öğretim için yeterli zaman ayırabilmekteyiz." S1

Okul öncesi ve sınıf öğretmenlerinin disiplinlerarası yaklaşımı kullanmak için öğrenci seviyelerinin yeterliliğine yönelik görüşleri Tablo 7'de sunulmuştur:

Tablo 7. Öğretmenlerin Öğrenci Seviyelerinin Yeterliliğine Yönelik Görüşleri

\begin{tabular}{lll}
\hline Branşlar & Temalar & Öğretmenler \\
\hline \multirow{2}{*}{ Okul öncesi } & Yeterli & O1, O2, O6, O7 \\
& Yetersiz & O5 \\
& Bazen Yeterli/Bazen Yetersiz & O1, O2, O6, O7 \\
\hline \multirow{2}{*}{ Sinıf } & Yeterli & S1, S2, S3, S5, S6, S7 \\
\hline
\end{tabular}

Tablo 7'de belirtildiği gibi okul öncesi öğretmenleri disiplinlerarası uygulamalar için öğrencilerin düzeylerini çoğunlukla yeterli bulmaktadırlar (f: 4). Araştırmadaki öğretmenlerden O5 yeterli görmemekte, $\mathrm{O} 3$ ve $\mathrm{O} 4$ ise bazen yeterli bazen yetersiz olarak değerlendirmektedirler. Araştırmada öğretmenlerden alınan cevapların bazıları şöyledir:

"Ailenin ilgisizliği, eğitim düzeyi, sosyoekonomik durum, bireysel farklılıklar nedeniyle yeterli değildir." $\mathrm{O} 5$

"Yeterli. Çocukların öğrenme seviyesi birbirinden farklı ya da ilgileri. Gün içinde birbiriyle bağlantılı olan etkinliklerimizde öğrenci birine ilgi duyup yapmasa da bir sonraki etkinlikte verilmek istenileni anliyor ve ögreniyor." $\mathrm{O} 2$ 
"Öğrenciler farklı bilgi ve beceride olduğu için buna genel bir cevap veremem. Ama yarı yarıya diyebilirim." $\mathrm{O} 4$

Tablo 7'de belirtildiği gibi sınıf öğretmenlerinin çoğu öğrencilerin düzeylerinin disiplinleraras1 yaklaşımı kullanmak için yeterli olduğunu belirtmişlerdir (f:6). Öğretmelerin verdikleri cevapların bazıları şu şekildedir:

“Sınıfta çok farklı özellikte öğrenci var. Disiplinlerarası ögretime uygun öğrenciler var.” S1

"İlgili ailelerin çocuklarının buna daha uygun olduğunu, hazırbulunuşluklarının yeterli seviyede olduğunu düşünüyorum. Tam ögrenmenin sağlanabilmesi için zamanın yeterli olmadığını düşünüyorum." S2

"Öğrencilerdeki bireysel farklılıkların disiplinlerarası ögretimde kullanılan yöntem açısından belirleyici olduğunu düşünüyorum.” S6

"Yeterli olduğunu düşünüyorum ama eğitim sistemimizin ögrencilerin ilgi ve yeteneklerine göre olduğunu düşünmüyorum.” S7

"Uygun olduğunu düşünüyorum. Okul öncesi eğitimle gelenlerin okul kurallarl, sinıf kuralları, sayı okuma ve yazmada hazır oluyorlar." S5

"Köy yerleşim yerlerinde öğrenciler kendi çabalarlyla ve birebir ögretmenle ders işleme imkânlarının az olmasl sebebiyle kapasite ve yeteneklerini tam olarak ortaya çıkaramayabiliyorlar. Bu yönde de sinıf ögretmenine daha fazla yük biniyor. Evde ailelerin ögretime katkı sağlama imkânı olmaması da çocukların eğitimini olumsuz etkiliyor. Disiplinler arası ilişkilendirilmede fazla ă̆ırlık verilemiyor." S4

Okul öncesi ve sınıf öğretmenlerinin disiplinlerarası yaklaşımı kullanmak için okul imkânlarının yeterliliğine yönelik görüşleri Tablo 8'de sunulmuştur:

Tablo 8. Öğretmenlerin Okul İmkânlarının Yeterliliğine Yönelik Görüşleri

\begin{tabular}{lll}
\hline Branşlar & Temalar & Öğretmenler \\
\hline \multirow{2}{*}{ Okul öncesi } & Yeterli & O3, O4 \\
& Kısmen Yeterli & O6, O7 \\
& Yetersiz & O1, O2, O5 \\
\hline \multirow{2}{*}{ Sınıf } & Yeterli & S3, S7 \\
& Kismen Yeterli & S4 \\
& Yetersiz & S1, S2, S5, S6 \\
\hline
\end{tabular}

Tablo 8'de okul öncesi öğretmenlerinin çoğu çalıştıkları okul imkânlarının disiplinlerarası yaklaşımı uygulamak için yetersiz (f: 3 ) olduğunu ileri sürmüşlerdir. Okul imkânlarının yeterli (f: 2) ve kısmen yeterli (f: 2) olduğunu düşünen öğretmenler de olmuştur. Araştırmaya katılan öğretmenlerden bazılarının görüşleri şu şekildedir:

"Fiziksel olarak yeterli değil, sınıflarımız alan olarak küçük, bahçemiz okul öncesine yönelik değil. Ancak elden geldiğince kullanılmaya, yararlı olması için çalışılıyor." $\mathrm{O} 7$

“..Sınıfımızın büyüklüğ̈̈ yeterli ancak bazı materyallerimiz yok.” O6

"Fen etkinliklerinde kullanabileceğim materyallerde eksiklik var." $\mathrm{O} 1$

"Bahçeyi kullanmamız gereken etkinliklerde sıkıntılar yaşıyoruz." $\mathrm{O} 2$

"Fiziksel ortam olarak spor alanı, bahçemizin olmayışı çocukların bahçe ile uğraşıp tohum, fidan dikme gibi bir olană̆ olmuyor. Bahçede oyun alanının olmaması, çocukların ilgi alanlarına göre atölyelerin ve materyallerin olmamast..." $\mathrm{O} 5$.

Tablo 8'e göre sınıf öğretmenlerinin çoğu disiplinlerarası yaklaşımı uygulamak için çalıştıkları okulun imkânlarının yetersiz olduğunu (f: 4) belirtmişlerdir. Öğretmenlerin bazılarının vermiş oldukları yanttlar şu şekildedir: 
"Okulumuz birleştirilmişs sınıflı köy okulu olduğu için kendi imkânları doğrultusunda materyal ve donanım sağllyor. Bu nedenle her alanda, her derste ilgili araç-gereç bulamıyoruz. Ulaşım ve benzeri ihtiyaç içeren kazanımların verilmesinde fiziki şartlar olumsuzluk yaratsa da, çevre ve doğa ile ilgili kazanımlarda olumlu şartlara sahip olduğumuzu düşünüyorum." S4

"Çok çok daha farklı eğitim-ögretim ortamlart tasarlanabilir. Okulumuzun bu vasıflara haiz olduğunu çok da düşünmüyorum. Doğa ile, hayvanlar ile daha yakın temas sağlanacak ortamlar olmalt." S6

Okul öncesi ve sınıf öğretmenlerinin disiplinlerarası yaklaşımı kullanmak için zümreleri arasındaki iletişimin/etkileşimin yeterliliğine yönelik görüşleri Tablo 9'da sunulmuştur.

Tablo 9. Öğretmenlerin Zümreleri Arasındaki İletişimin/Etkileşimin Yeterliliğine Yönelik Görüşleri

\begin{tabular}{lll}
\hline Branşlar & Temalar & Öğretmenler \\
\hline Okul öncesi & Yeterli & O1, O2, O3, O4, O5, O6, O7 \\
& Yetersiz & - \\
\hline \multirow{2}{*}{ Sınıf } & Yeterli & S3, S5, \\
& Yetersiz & S1, S2, S4, S6, S7 \\
\hline
\end{tabular}

Tablo 9'da görüldüğü gibi okul öncesi öğretmenler disiplinlerarası yaklaşımın uygulanabilmesi için zümreleri ile iletişim ve işbirliğinin yeterli olduğunu düşünmektedirler (f: 7). Öğretmenlerin ifadelerinden bazıları şöyledir:

"Öğretmenler arası iletişsim iyi. Fakat eğitim amaçlı planlı olarak bir araya gelmiyoruz. Bunun en önemli sebeplerinin başında kıdem farkı olması. Çünkü emekliliğe yakın öğretmenler yeniliklere açık değiller." $\mathrm{O} 7$

"Normal etkinliklerde birbirimizden fikir alışverişi yapıyoruz. Ama disiplinlerarası ögretim için iletişimimiz olmadl." O5

Tablo 9'da görüldüğü gibi sınıf öğretmenlerinin çoğunluğu disiplinlerarası yaklaşımı uygulayabilmek için zümreleri arasındaki işbirliğinin ve iletişimin yetersiz olduğunu öne sürmektedir. Öğretmenlerin ifadelerinden bazıları şöyledir:

"Zümreler arası iletişsimin olduğunu ama yine de her sinıftaki öğrenci potansiyelinin birbirinden farklı olması sebebiyle ögretmenlerin uygulama şekillerinin de değiştirildiğini düşünüyorum. Ve bu sebeple disiplinler arası geçiş için zümreler arası işbirliği olmadığını söyleyebilirim." S2

"Zümreler arası işbirliğinde rekabet ön planda olduğu için değil disiplinlerarası öğretimi uygulama diğer konularda bile paylaşım çok az." S6

“Zümreler arası iletişim var. Etkinlikleri beraber planliyoruz. Uyguluyoruz." S5

"Birleştirilmiş sinıflı köy okulunda tek başına görev yapmaktayım. Bu nedenle zümre işbirliği söz konusu mümkün olmuyor." S4

\section{Öğretmenlerin Disiplinlerarası Yaklaşımın Kullanımına Yönelik Önerileri}

Araştırmaya katılan öğretmenlerin bazılarının disiplinlerarası yaklaşımı uygulayabilme yönündeki önerileri şu şekildedir:

"Disiplinlerarası yaklaşım konusunda yeterli olduğumu düşünmüyorum. Seminer verilmesinin gerekliliğine inaniyorum. Sik sık bilgilendirilmemiz gerektiğini düşünüyorum." O5

"Disiplinlerarası yaklaşımlar konusunda bilgilerimizi güncellemek amacıyla zaman zaman bilgilendirme amaçlı seminerler yapılabilir." $\mathrm{O} 2$

"Okul öncesinde öğrencilerine daha iyi bir disiplinlerarası eğitim verebilmek için üniversitede ögrencilere bu yaklaşım daha iyi öğretilmeli. Çünkü staja gelen, stajyer öğrenciler de disiplinlerarası yaklaşıma göre ders etkinliklerini yapmakta ön bilgilerinin yetersiz olduğunu düşünüyorum.” $\mathrm{O} 7$ 
"Birleştirilmiş sınıflı köy okullarının imkânlar bakımından daha da pozitif hale getirilmesi gerektiğini düşünüyorum. Bu konuda disiplinlerarası yaklaşım konusunda birleştirilmiş sınıflarda öğretmenögrenci işbirliği yapılabileceğine inanıyorum." S4

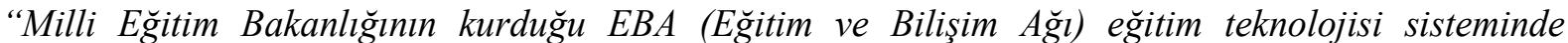
ilkögretime yönelik ne Bakanlık ne de eğitimle ilgili yayın kuruluşlarının hiçbir etkinliği yoktur. Olursa daha yararlı olur diye düşünüyorum. "S5

\section{TARTIŞMA, SONUÇ VE ÖNERILER}

Araştırma sonucunda sınıf öğretmenlerinin disiplinlerarası yaklaşımı tanımlama konusunda okul öncesi öğretmenlerine göre daha iyi durumda oldukları görülmüştür. Sınıf öğretmenlerinin çoğu disiplinlerarası yaklaşımı "bir konunun birden fazla farklı dersin kazanımlarıyla ilişskilendirilmesi" olarak tanımlamışlardır. Arslantaş (2006) çalışmasında disiplinlerarası öğretim yaklaşımını bir konunun, kavramın iki ya da daha fazla disiplinle ilişkilendirilerek öğretilmesi şeklinde açıklamıştır. Buradan sınıf öğretmenlerinin yapmış oldukları tanımdan bir konuyu en az iki disiplinle ilişkilendirerek öğretilmesinin disiplinlerarası ilişkilendirme olduğunu bildikleri sonucuna varılabilir. Bir sınıf öğretmeni hariç tüm öğretmenler disiplinlerarası yaklaşımı kullandıklarını ifade etmişlerdir. Karakuş ve Aslan (2016), yapmış oldukları çalışmalarında öğretmenlerin bir konuyu öğretirken farklı disiplinlerle ilişkilendirdiklerini ifade etmişlerdir. Öğretmenlerin disiplinlerarası yaklaşımı kullanma nedenleri incelendiğinde; okul öncesi öğretmenlerinin genel olarak bu yaklaşımı öğrencilerin farklı açılardan öğrenme becerileri geliştirdiğini, farklı zekâ alanlarına hitap ettiğini ve öğretimi kolaylaştırdığını düşündükleri için kullandıkları, sınıf öğretmenlerinin ise bu yaklaşımın konuları pekiştirmekte etkili olduğunu düşündükleri için kullandıkları sonucuna ulaşılmıştır. Ayrıca okul öncesi öğretmenlerinin ifade ettikleri kullanma nedenlerinin sınıf öğretmenlerine göre daha fazla çeşitlendiği tespit edilmiştir. Arslantaş (2013), ilkokul 4.sınıf öğrencileriyle yürüttüğü çalışmasında, görsel sanatlar dersinde disiplinlerarası yaklaşımı kullanarak öğrencilerin derse yönelik tutumunu, eleştirel düşünmesini, öğrenci ürününün niteliğini ve öğrencilerin öğrenme-öğretme sürecindeki düşüncelerini incelemiştir. Araştırmacı disiplinlerarası yaklaşıma dayalı görsel sanatlar dersinin öğrencilerin eleştirel düşünme becerilerini ve ortaya koydukları ürünün niteliğini olumlu yönde etkilediğini tespit etmiştir. Disiplinlerarası yaklaşımın faydaları ise öğrenmede kolaylık sağlama, yaşamla ilişkilendirme, somutlaştırma, ilgi çekip merak uyandırma, konunun pekiştirilmesi, öğrenmeyi kalıcı hale getirme, akademik başarıyı artırma şeklinde sıralanabilir (Karakuş, Turhan Türkkan ve Karakuş, 2017; Matthewsi, Adams ve Goos, 2009; Elliott, Oty, Mcarthur ve Clark, 2001; Demirel, Tuncel, Demirhan ve Demir, 2008; Gürkan, 2019). Yapılan araştırmada da öğretmenlerin disiplinlerarası yaklaşımı tercih etme nedenleri konusunda bilinçli oldukları söylenebilir.

Öğretmenlerin disiplinlerarası yaklaşımı kullanmaya uygun buldukları konular incelendiğinde okul öncesi öğretmenlerinin çoğunlukla çevre, sağlıkla ilgili konular ile fen ve matematikle ilgili konuları disiplinlerarası öğretime uygun buldukları; sınıf öğretmenlerinin ise çoğunlukla matematik ve sağlık ile ilgili konuları disiplinlerarası öğretime uygun buldukları sonucuna ulaşılmıştır. Karakuş, Turhan Türkkan ve Karakuş (2017)'un çalışmalarında, Fen Bilgisi öğretmenlerinin derslerinde disiplinlerarası yaklaşımla ilişki kurdukları konuların daha çok matematiksel hesaplamalar, dünyanın yapısı ve oluşumu, ses ve notalar olduğu görülürken; Matematik öğretmenlerinin ise derslerinde en fazla fen bilgisi dersine yönelik sayısal hesaplamalar, perspektif ve hız konularını disiplinlerarası yaklaşımla ilişkilendirdikleri görülmüştür. Yapılan bazı çalışmalar doğrultusunda matematik ve fen bilgisi derslerinin arasında kuvvetli bir bağ olduğu belirtilmiş olup bu derslerin birbiri içerisine sık sık geçişlerin olduğu ileri sürülmüştür (Keşan ve Kaya, 2008; Taşdemir ve Taşdemir, 2011). Bir başka çalışmada disiplinler arası yaklaşımla değer öğretiminde yaratıcı drama yönteminin kullanılmasında öğrenciler için eğlenceli ortam oluşturduğu, değerlerin kazandırılmasında etkili sonuçlar elde edildiği, öğrenmelerin somutlaştırıldığ 1 tespit edilmiştir (Çelik ve Buluç, 2018). Araştırma bulgularının matematik ve fen ile ilgili konuların disiplinlerarası öğretime uygun olduğunu ortaya koyan çalışmaların bulguları ile tutarlı olduğu söylenebilir.

Öğretmenlerin disiplinlerarası yaklaşımı kullanırken konuları ilişkilendirdikleri dersler incelendiğinde okul öncesi öğretmenlerinin çoğunlukla Türkçe, Müzik ve Fen Bilimleri dersi; sınıf öğretmenlerinin ise matematik, Türkçe ve görsel sanatlar dersleri ile ilişkilendirdikleri tespit edilmiştir. Yine Karakuş, 
Turhan Türkkan ve Karakuş (2017)'un çalışmalarında fen bilgisi öğretmenlerinin en fazla matematik, sosyal bilgiler ve Türkçe derslerini disiplinlerarası yaklaşım doğrultusunda ilişkilendirdikleri; matematik öğretmenlerininse en fazla fen bilgisi, görsel sanatlar, sosyal bilgiler, teknoloji ve tasarım derslerini ilişkilendirdikleri tespit edilmiştir. Bir başka çalışma olan fen bilgisi öğretmen adaylarının disiplinlerarasındaki ilişkiye yönelik görüşlerinde, veriler çizim yolu ile elde edilmiş ve öğretmen adaylarının fen bilimlerinin bazı disiplinleri kapsadığını, bazı disiplinlerin birbiriyle ilișkili veya bağlantılı olduğunu ve bazı disiplinlerin de ortak noktalarının olduğunu düşündükleri tespit edilmiştir (Kızılay ve Saylan Kırmızıgül, 2019). Bu çalışmaların sonucundan da anlaşılacağı üzere okul öncesi ve ilköğretim öğrenci seviyelerinin, öğretim programı ders içeriklerinin disiplinlerarası yaklaşımın kullanılmasında uygun olduğu, ayrıca öğretmenlerin de bu yaklaşımın derslerde kullanılmasının fayda sağlayacağını düşündükleri varsayılabilir.

Disiplinlerarası yaklaşımı kullanmak için ders saatlerinin yeterliliği konusunda; okul öncesi ögretmenlerin çoğu yeterli olduğu yönünde görüş bildirirken, sınıf öğretmenlerinin çoğu yetersiz veya bazen yeterli şeklinde görüş bildirmişlerdir. Alan yazında, disiplinlerarası yaklaşımın sınırlılıkları arasında zaman unsuru ile ilgili olarak programın yetiştirilememesi bulunmaktadır (Matthews, Adams ve Goos, 2009). Bir başka çalışmada öğretmenler disiplinlerarası yaklaşımı uygulamada öğretim kaynaklarının yetersizliğinden, yeterli zamanın olmamasından, teknolojik destek ihtiyaçlarından ve uygun sınıf ortamlarının olmamasından dolayı zorluk yaşadıklarını ifade etmiş̧lerdir (Gürkan, 2019). Disiplinlerarası yaklaşımı kullanmak için öğrenci seviyelerinin yeterliliği konusunda, sınıf ögretmenlerinin görüşlerinin okul öncesi öğretmenlerinin görüşlerine göre daha olumlu olduğu tespit edilmiştir. Bu sonucu sınıf öğretmenlerinin yapmış olduğu açıklamadan biri olan 'birinci sınıfa gelen ögrencilerin çoğunluğu okul öncesi ĕgitimi aldıkları için derslerde disiplinlerarası yaklaşımı kullanmada ögrrenci yeterliliği sağlaniyor' şeklindeki çıkarımı sınıf öğretmenlerinin, okul öncesi öğretmenlerine göre öğrencilerini yeterli seviyede görme sebeplerinden biri olarak varsayılabilir. Disiplinlerarası yaklaşımı kullanmak için okul imkânlarının yeterliliği konusunda ise okul öncesi ve sınıf ögretmenlerinin çoğunun yetersiz olduğu yönünde görüş bildirdikleri ortaya koyulmuştur. Yapılan bir araştırmada da öğretmenler disiplinlerarası yaklaşım açısından programı uygulama sürecinde ders kitaplarının yüzeysel olması, okullardaki alt yapı eksikliği gibi zorluklarla karşılaştıklarını belirtmişlerdir (Saraç ve Yıldırım, 2019).

Disiplinlerarası yaklaşımı kullanmak için zümreleri arasındaki iletişimin/etkileşimin yeterliliği konusunda ise okul öncesi öğretmenlerin tamamının yeterli olduğu yönünde görüş bildirdikleri ancak bazı öğretmenler ise disiplinlerarası yaklaşımı etkinliklerde kullanabilmek için özel olarak bir araya gelip işbirliği yapmadıklarını belirtmişlerdir. Sınıf öğretmenlerinin ise çoğunluğunun zümreleri arasındaki iletişimin/etkileşimin yetersiz olduğu yönünde görüş bildirdikleri tespit edilmiştir. Disiplinlerarası yaklaşımın doğası gereği öğretmenlerin iş birliği yapmamaları istenmeyen bir durumdur. Bazı çalışmalarda ise öğretmenlerin disiplinlerarası yaklaşım bağlamında meslektaşlarıyla yaptığı işbirliğinin yalnızca planlamada, konu sıralamasında ve bilgi alış verişine yönelik olduğu görülmüştür (Karakuş, Turhan Türkkan ve Karakuş (2017). İmamoğlu ve Çeken (2011), disiplinlerarası yaklaşım ile ders etkinlikleri hazırlamanın, planlama ve düzenlenme aşamasında öğretmenlerin zümreleri ile işbirliği yapmalarını gerektirdiğini savunmuşlardır. Çalışmada sınıf ögretmenlerinin iletişimlerinin yetersiz olduklarını ifade etmeleri dikkat çeken bir durumdur. Son olarak öğretmenler genel olarak disiplinlerarası yaklaşımı uygulayabilmeleri konusunda eğitsel (mesleki gelişim desteği), fiziksel imkânlar ve teknolojik olarak desteklenmeleri gerektiklerini ifade etmişlerdir. Çalışmanın sonucu ve yapılan farklı araştırmaların sonuç ve önerileri doğrultusunda, disiplinlerarası yaklaşımın öğretimde verimli bir şekilde kullanılması için araştırmacıların verdiği önerilerin dikkate alınması önemli görülmektedir. Bu öneriler şu şekildedir:

- Disiplinlerarası yaklaşımı kavrayabilmeleri açısından öğretmen adaylarına derslerde örnek etkinlik geliştirme şeklinde bir eğitim içeriği sunulmalıdır. İş başındaki öğretmenlere ise hizmet içi eğitimlerde bu yaklaşım daha yakından tanıtılmalı, ayrıca ders uygulamalarında öğretmenler desteklenmeli, zaman kullanımı açısından da eksiklikleri giderilmelidir. 
- Okul öncesi ve ilkokul öğrenci seviyesinde disiplinlerarası yaklaşımın kullanılması öğretim programlarında da vurgulanmalı, öğretim programlarında bu yaklaşımın nasıl uygulanabileceği konusunda öğretmenlere yönelik açıklamalar bulunmalıdır.

- Disiplinlerarası yaklaşımın doğası gereği öğretmenler arası işbirliğinin sağlanması açısından, hizmet içi eğitimlerde, öğretmenlerin işbirliği halinde çalışabilecekleri uygulamalar yer almalidir.

- Disiplinlerarası yaklaşımın kullanılmasında okulun fiziki șartları ve materyal olanakları etkilidir. Bu açıdan ihtiyaçların imkânlar doğrultusunda giderilmesi gerekmektedir. Dünyadaki tüm okulların olanaklarının ekonomik sebeplerle eşit olamaması göz önünde bulundurularak hizmet içi eğitimlerde her okulun kendi olanaklarının disiplinlerarası öğretim açısından en üst düzeyde faydalanılması yönünde öğretmenlere teşvik edici bilgilendirmeler, etkinlikler ve toplu görüşmelerle fikir alış verişi yapılmasının fayda sağlayacağı düşünülmektedir.

Bilgilendirme / Acknowledgement:

1- Araştırmacıların katkı oranı eşittir.

2- Makalenin yazarları arasında çıkar çatışması bulunmamaktadır

3- Makalemizdeki veriler 2019 yılında derlenmiş ve yorumlanmıştır.

4- Bu makalede araştırma ve yayın etiğine uyulmuştur.

\section{KAYNAKÇA}

Arslantaş, B. (2006). İlköğretim 4.sınıf beden eğitimi dersi futbol temel becerilerinin disiplinlerarası ögretim yaklaşımına göre ögretiminde bir model uygulama. Yayımlanmamış yüksek lisans tezi, Marmara Üniversitesi Eğitim Bilimleri Enstitüsü, İstanbul.

Arslantaş, S. (2013). İlköğretim 4.sınıf görsel sanatlar dersinde disiplinlerarası yaklaşıma göre yapılan öğretimin öğrencilerin derse ilişkin tutumlarına etkisi. Gaziosmanpaşa Bilimsel Araştırma Dergisi, 2, 1-13.

Aybek, B. (2001). Disiplinlerarası (bütünleştirilmiş) öğretim yaklaşımı. Eğitim Araştırmaları Dergisi, $3,1-7$.

Aydın, G. ve Balım, A. G. (2008). Yapılandırmacı yaklaşıma göre modellendirilmiş disiplinlerarası uygulama: Enerji konularının öğretimi. Ankara Üniversitesi Eğitim Bilimleri Fakültesi Dergisi, 38(2), 145-166.

Aytar, A. ve Özsevgeç, T. (2019). Disiplinler arası fen öğretiminin 7.sınıf öğrencilerinin sürdürülebilir kalkınma konusundaki gelişimlerine etkisi. Hacettepe Üniversitesi Eğitim Eğitim Fakültesi Dergisi, 34(2), 324-357.

Büyüköztürk, S., Kılıç-Çakmak, E., Akgün, Ö. E., Karadeniz, S. ve Demirel, F. (2012). Bilimsel araştırma yöntemleri. Ankara: Pegem Akademi Yayımcılık.

Choi, B.C.K. ve Pak, A.W.P. (2006). Multidisciplinarity, interdisciplinarity and transdisciplinarity in health research, sevices, education and policy: 1. Definitios, objectives and evidence of effectivenes. Clinical and Investigative Medicine, 29(6), 351.

Çelik, Ö. ve Buluç, B. (2018). Disiplinler arası yaklaşımla değer öğretiminde yaratıcı drama yönteminin kullanılması. Erzincan Üniversitesi Eğitim Fakültesi Dergisi, 20(1), 67-88.

Demir, E. (2009). İlköğretim ikinci sinıflarda uygulanan disiplinlerarası bütüncül öğretim yaklaşımının etkisi. Yayımlanmamış doktora tezi, Selçuk Üniversitesi Sosyal Bilimleri Enstitüsü, Konya. 
Demirel, Ö. Tuncel, İ., Demirhan, C. ve Demir, K. (2008). Çoklu zekâ kuramı ile disiplinlerarası yaklaşımı temel alan uygulamalara ilişkin öğretmen-öğrenci görüşleri. Eğitim ve Bilim, 33(147), 14-25.

Doğan, C. (2014). Coğrafya öğretiminde disiplinlerarası ders iş̧lenişinin başartya etkisinin değerlendirilmesi. Yayımlanmamış yüksek lisans tezi, Gazi Üniversitesi Eğitim Bilimleri Enstitüsü, Ankara.

Elliott, B., Oty, K., Mcarthur, J. ve Clark, B. (2001). The effect of an interdisiplinary algebra / science course on students' problem solving skills, critical thinking skills and attitudes towards mathematics. International Journal of Mathematical Education in Science and Technology, 32(6), 811-816.

Erkuş, A. (2005). Bilimsel araştırma sarmall. Ankara: Seçkin Yayıncılık.

Focht, W. ve Abramson, C. I. (2009). The case for interdisciplinary environmental education and research. American Journal of Environmental Sciences, 5(2), 124-129.

Gülay Ogelman, H. ve Durkan, N. (2014). Toprakla buluşan çocuklar: Küçük çocuklar için toprak eğitimi projesinin etkililiği. Uluslararası Sosyal Araştırmalar Dergisi, 7(31), 632-638.

Gürkan, B. (2015). Dördüncü sınıf sosyal bilgiler dersinde kavramsal anlama becerilerinin geliştirilmesinde bağlamsal ögrenme yaklaşımına dayalı disiplinler arası öğretim uygulamaları: bir durum çalışması. Yayımlanmamış doktora tezi, Çukurova Üniversitesi Sosyal Bilimler Enstitüsü, Adana.

Gürkan, B. (2019). Ortaokul öğretmenlerinin disiplinlerarası öğretim uygulamalarına ilişkin görüşlerinin incelenmesi. Pegem Ĕ̆itim ve Öğretim Dergisi, 9(1), 91-124.

Hinde, E. R. (2005). Revisiting curriculum integration: A freshlook at an old idea. The Social Studies, 96(3), 105-111.

İmamoğlu, H. V. ve Çeken, R. (2011). İlköğretim sosyal bilgiler dersinin bilim tarihi açısından fen ve teknoloji dersi ile ilişkilendirilmesi üzerine disiplinlerarası bir bakış. Ordu Üniversitesi Sosyal Bilimler Enstitüsü Sosyal Bilimler Araştırmaları Dergisi, 2(3), 71-87.

Jocobs, H.H. (1989). Design options for an integration curriculum, H. H. Jacobs (Ed). Interdisciplinary curriculum: Design and implementation. Alexandria, VA: ASCD.

Kanatlı, F. ve Çekici, Y. (2013). Türkçe öğretiminde disiplinlerarası olanaklar. Mersin Üniversitesi Eğitim Fakültesi Dergisi, 9(2), 223-234.

Karakuş, M. ve Aslan, S. (2016). İlkokulda disiplinlerarası öğretime yönelik mevcut durumun incelenmesi. Elementary Education Online, 15(4), 1325-1344.

Karakuş, M., Turhan-Türkkan, B. ve Karakuş, F. (2017). Fen bilgisi ve ilköğretim matematik öğretmenlerinin disiplinlerarası yaklaşıma yönelik görüşlerinin belirlenmesi, Elementary Education Online, 16(2), 509-524.

Keşan, C. ve Kaya, D. (2008). Fen öğretiminde hibritleştirilmiş bir öğrenme ortamı nasıl olmalı? Bilim, Eğitim ve Düşünce Dergisi, 8(4). 1 Haziran 2019 tarihinde http://fenliler.blogspot.com/2011/08/fen-ogretiminde-hibritlesmis-bir.html adresinden erişildi.

Kızılay, E. ve Saylan Kırmızıgül, A. (2019). Disiplinler arasındaki ilişkiye dair fen bilgisi öğretmen adaylarının görüşleri. Adnan Menderes Eğitim Fakültesi Dergisi, 10(1), 1-9.

Matthews, K. E., Adams, P. ve Goos, M. (2009). Putting into perspective: Mathematics in the undergraduate science curriculum. International Journal of Mathematical Education in Science and Technology, 40(7), 891-902.

Miles, M. B. ve Huberman A. M. (1994). Qualitative data analysis: an expanded source book. Thousand Oaks, CA: Sage. 
Özkök, A. (2005). Disiplinlerarası yaklaşıma dayalı yaratıcı problem çözme öğretim programının yaratıcı problem çözme becerisine etkisi. Hacettepe Üniversitesi Ë̆itim Fakültesi Dergisi, 28, 159-167.

Saraç, E. ve Yıldırım, M.S. (2019). Fen bilimleri dersi öğretim programına yönelik öğretmen görüşleri. Academy Journal of Education Sciences, 3(2), 138-151.

Skelly, S. M. ve Zajicek, J. M. (1998). The effect of an interdisciplinary garden program on the environmental attitudes of elementary school students. Hort Teknology, 8(4), 579- 583.

Subaşı, M. ve Okumuş, K. (2017). Bir araştırma yöntemi olarak durum çalışması. Atatürk Üniversitesi Sosyal Bilimler Enstitüsü Dergisi, 21(2), 419-426.

Taşdemir, M. ve Taşdemir, A. (2011). İlköğretim müfredatındaki fen ve dil temelli derslerin disiplinlerarası yaklaşımla incelenmesi. Fırat Üniversitesi Sosyal Bilimler Dergisi, 21(1), 217232.

Turan, S. (2019). 2018 Sosyal bilgiler öğretim programının disiplinlerarası yapısının incelenmesi. Journal of Innovative Research in Social Studies, 2(2), 166-190.

Uğraş, M. (2017). Okul öncesi öğretmenlerinin stem uygulamalarına yönelik görüşleri. Eğitimde Yeni Yaklaşımlar Dergisi, 1(1), 39-54.

Yıldırım, A. (1996). Disiplinlerarası öğretim kavramı ve programlar açısından doğurduğu sonuçlar. Hacettepe Üniversitesi Ĕ̈itim Fakültesi Dergisi, 12, 89-94.

Yıldırım, A. ve Şimşek H. (2013). Sosyal bilimlerde nitel araştırma yöntemleri. Ankara: Seçkin Yayınc1lı. 